\title{
Pemenuhan Hak Pendidikan Bagi Penyandang Disabilitas Perspektif Hukum Nasional dan Hukum Islam
}

\author{
Hendra Dude, Fenty U. Puluhulawa, Nina Mirantie \\ Pascasarjana Universitas Negeri Gorontalo; Universitas Negeri Gorontalo \\ Email: hendradude04@gmail.com; fentypuluhulawa@ung.ac.id; \\ ninamirantie@ymail.com
}

\begin{abstract}
This research discusses the fulfillment of the right to education for persons with disabilities. After the enactment of Law Number 8 of 2016, one of the government's obligations is to guarantee the right to education. This research is library research that is analyzed descriptively qualitatively with the approach of national law and Islamic law. The results showed that: first, Islamic law regulates equal rights in education without any distinction between physically normal people and people with disabilities. Likewise, national law has been regulated in Law Number 8 of 2016. However, this regulation needs to be followed up in the form of an implementing regulation to ensure that its compliance policies have a legal basis in the form of regional regulations. Second, the authority of local governments as stated in Law Number 23 of 2014 concerning Regional Government has mandated regions to administer education as a mandatory government affair related to basic services so that local governments in managing education must carry out their obligations to fulfill the right to education. to the community, especially for people with disabilities.
\end{abstract}

Keywords: Education Rights, Disabled Person

\section{Fulfilling the Right to Education for Persons with Disabilities Perspective of National Law and Islamic Law}

\begin{abstract}
Abstrak: Penelitian ini membahas pemenuhan hak pendidikan bagi penyandang disabilitas. Pasca pemberlakuan Undang-Undang Nomor 8 Tahun 2016, salah satu bentuk kewajiban pemerintah adalah memberikan jaminan terhadap hak pendidikan. Penelitian ini adalah penelitian kepustakaan yang dianalisis secara deskriptif kualitatif dengan pendekatan hukum nasional dan hukum Islam. Hasil penelitian menunjukkan bahwa: pertama, hukum Islam mengatur kesamaan hak dalam pendidikan tanpa adanya pembedaan antara yang fisiknya normal maupun penyandang disabilitas. Begitu pula hukum nasional telah diatur dalam Undang-Undang Nomor 8 Tahun 2016. Namun, aturan tersebut perlu ditindaklanjuti dalam bentuk peraturan pelaksana guna memastikan kebijakan pemenuhannya memiliki landasan hukum berupa peraturan daerah. Kedua, kewenangan pemerintah daerah yang tercantum dalam Undang-Undang Nomor 23 Tahun 2014 tentang Pemerintahan Daerah telah memberikan mandat kepada daerah untuk mengurus pendidikan sebagai urusan pemerintahan wajib yang berkaitan dengan pelayanan dasar, sehingga pemerintah daerah dalam mengelola pendidikan mesti melaksanakan kewajibannya untuk melakukan pemenuhan hak pendidikan kepada masyarakat khusunya bagi penyandang disabilitas.
\end{abstract}

Kata Kunci: Hak Pendidikan, Penyandang Disabilitas 


\section{A. Pendahuluan}

Pendidikan merupakan hak asasi manusia yang dijamin oleh Undang-Undang Dasar Negara Republik Indonesia (UUD NRI) Tahun 1945 sebagai bentuk tanggung jawab negara atas pengembangan sumber daya manusia. Pendidikan mempunyai peranan sangat strategis dalam pembangunan suatu bangsa yang merupakan investasi masa depan kemajuan bangsa dan negara. Pemerintah wajib memberikan layanan dan kemudahan, serta menjamin terselenggaranya pendidikan yang bermutu bagi setiap warga negara tanpa diskriminasi. ${ }^{1}$ Hal ini merupakan hak asasi setiap manusia, khususnya warganegara Indonesia.

Hak pendidikan ini juga berlaku kepada orang berkebutuhan khusus (penyandang cacat) atau yang biasa disebut difabel. Penyelenggaraan sistem pendidikan yang tertuang dalam Undang-Undang Nomor 20 Tahun 2003 tentang Sistem Pendidikan Nasional telah menempatkan setiap warga negara mempunyai hak yang sama untuk memperoleh hak pendidikan yang bermutu dimana warga negara yang memiliki kelainan fisik, emosional, mental, intelektual atau sosial berhak memperoleh pendidikan khusus.

Selain aturan hukum nasional, hukum Islam pun sangat menjunjung tinggi terhadap persamaan hak-hak setiap manusia. Hal ini dapat dilihat dari beberap pernyataan dalam Alquran, seperti: QS al-Hujurat/49: 13 bahwa tidak ada perbedaan laki-laki dan perempuan, semuanya diciptakan untuk saling kenal-mengenal dan hanya takwalah yang membedakan di sisi Allah swt. Juga dijelaskan dalam QS Abasa/80: 111 bahwa tidak ada pembedaan antara yang fisiknya normal dan fisiknya tidak normal (penyandang disabilitas) dalam hal mendapatkan pengajaran.

Penyandang disabilitas memiliki kedudukan, hak dan kewajiban yang sama dengan masyarakat non disabilitas. Sebagai bagian dari warganegara Indonesia, sudah sepantasnya penyandang disabilitas mendapatkan perlakuan khusus, yang dimaksudkan sebagai upaya perlindungan dari kerentanan terhadap berbagai tindakan diskriminasi dan terutama perlindungan dari berbagai pelanggaran hak asasi manusia. Perlakuan

${ }^{1}$ Republik Indonesia, Undang-Undang Nomor 20 Tahun 2003 tentang Sistem Pendidikan Nasional, Pasal 11 Ayat 1. 
khusus tersebut dipandang sebagai upaya maksimalisasi penghormatan, pemajuan, perlindungan dan pemenuhan hak asasi manusia universal. ${ }^{2}$

Penyandang disabilitas merupakan kelompok masyarakat yang beragam, diantaranya penyandang disabilitas yang mengalami disabilitas fisik, disabilitas mental maupun gabungan dari disabilitas fisik dan mental. Kondisi penyandang disabilitas tersebut mungkin hanya sedikit berdampak pada kemampuan untuk berpartisipasi di tengah masyarakat, atau bahkan berdampak besar sehingga memerlukan dukungan dan bantuan dari orang lain. ${ }^{3}$

Penghormatan, pelindungan, dan pemenuhan hak pendidikan bagi penyandang disabilitas merupakan kewajiban negara. Hal ini juga ditegaskan dalam UndangUndang Nomor 39 Tahun 1999 tentang Hak Asasi Manusia, sehingga masyarakat mempunyai tanggung jawab untuk menghormati hak penyandang disabilitas. Penyandang disabilitas selama ini belum menjadi agenda prioritas bagi pemerintah sehingga berakibat belum terpenuhinya pelaksanaan hak pendidikan bagi penyandang disabilitas.

Pasca lahirnya Undang-Undang Republik Indonesia Nomor 8 Tahun 2016 tentang Penyandang Disabilitas memberikan penguatan khususnya di sektor pendidikan. Pemerintah daerah diwajibkan untuk memberikan perlindungan penuh kepada penyandang disabilitas dalam memenuhi hak pendidikannya guna menyetarakan kepentingan mereka dengan masyarakat yang lain. Landasan hukum inilah menjadi keinginan bagi penyandang disabilitas untuk mendapatkan pendidikan yang layak sebagai tanggung jawab pemerintah daerah.

Kehadiran undang-undang tentang penyandang disabilitas semestinya relevan dengan semangat kebijakan hukum pemerintah daerah dalam melakukan langkahlangkah strategis untuk mengakomodir kepentingan penyandang disabilitas khususnya disektor pendidikan. Penting untuk disadari bahwa kurangnya perhatian pemerintah daerah terhadap hak pendidikan penyandang disabilitas akan menjadi tolak ukur sukses atau tidaknya program dan kebijakan pemerintah daerah untuk mencapaitujuan negara

\footnotetext{
${ }^{2}$ Majda El Muhtaj, Dimensi-Dimensi HAM Mengurai Hak Ekonomi, Sosial dan Budaya (Jakarta: Raja Grafindo Persada, 2008), 273.

${ }^{3}$ International Labour Office, Kaidah ILO tentang Pengelolaan Penyandang Cacat di Tempat Kerja (Jakarta: ILO Publication, 2006), 3.
} 
yang tertuang secara jelas dalam pembukaan UUD NRI Tahun 1945 yaitu mencerdaskan kehidupan bangsa tanpa diskriminasi.

Secara normatif pun, tugas pemerintah daerah telah diatur dalam UndangUndang Republik Indonesia Nomor 23 Tahun 2014 tentang Pemerintahan Daerah yang mana salah satu urusan pemerintahan wajib yang dilaksanakan oleh pemerintah daerah berkaitan dengan pelayanan dasar adalah pendidikan. ${ }^{4}$ Dengan demikian, pemerintah daerah memiliki landasan yang kuat dan kewenangan yang luas untuk mengatur dan mengelola pendidikan secara menyeluruh termasuk yang berhubungan dengan pendidikan bagi penyandang disabilitas.

\section{B. Pemenuhan Hak Penyandang Disabilitas Perspektif Hukum Islam}

Wahbah al-Zuhaili mengemukakan sebagaimana dikutip oleh Darwis bahwa fikih dari segi bahasa berasal dari akar kata fá, qăa, dan $h a(ف)$ (ف) yang berarti paham atau pengetahuan tentang sesuatu. ${ }^{5}$ Menurut istilah sebagaimana Ibn Manzur menyatakan bahwa kata al-fiqh berarti pengetahuan terhadap sesuatu atau pemahaman terhadap sesuatu, kemudian menjadi istilah khusus untuk ilmu-ilmu keagamaan, dan lebih khusus lagi untuk ilmu-ilmu hukum terkait kasus-kasus parsial. ${ }^{6}$

Hukum Islam dalam hal ini kaitannya dengan siyasah syar'iyyah. Secara etimologi siyasah syar'iyyah berasal dari kata syara'a yang berarti sesuatu yang bersifat syar'i atau bisa diartikan sebagai peraturan atau politik yang bersifat syar'i. Secara terminologis menurut Ibnu Akil adalah sesuatu tindakan yang secara praktis membawa manusia dekat dengan kemaslahatan dan terhindar dari kerusakan. ${ }^{7}$ Siyasah menurut bahasa juga mengandung beberapa arti, yaitu mengatur, mengurus, memerintah, memimpin, membuat kebijaksanan, pemerintahan dan politik. Secara terminologis dalam Kitab Lisan al-Arab, yang dimaksud dengan kata siyasah adalah mengatur atau memimpin sesuatu dengan cara yang membawa kepada kemaslahatan.

\footnotetext{
${ }^{4}$ Republik Indonesia, Undang-Undang Nomor 23 Tahun 2014 tentang Pemerintahan Daerah, Pasal 12 Ayat 1.

${ }^{5}$ Rizal Darwis, "Hak Nafkah Batin Suami Istri dalam Perkawinan: Telaah Fikih dan Hukum Nasional Perspektif Jender,” Disertasi (Makassar: UIN Alauddin Makassar, 2016), 24.

${ }^{6}$ Ibn Manzur, Lisān al- 'Arabī, juz 12 (Bairūt: Dār al-Fikr, 1994), 522.

${ }^{7}$ Wahbah al-Zuhaily, Ushul Fiqh: Kulliyat Da'wah al-Islami (Jakarta: Radar Jaya Pratama, 1997), 89 .
} 
Pada prinsipnya fiqh siyasah ialah ilmu yang mempelajari hal-ihwal urusan umat dan negara dengan segala bentuk hukum, pengaturan, dan kebijaksanaan yang dibuat oleh pemegang kekuasan yang sejalan dengan dasar-dasar ajaran syariat untuk mewujudkan kemaslahatan umat. ${ }^{8}$

Menurut al-Mawardi bahwa ruang lingkup kajian fiqh siyasah mencakup kebijaksanaan pemerintah tentang peraturan perundang-undangan (siyasah dusturiyah), ekonomi dan militer (siyasah maliyah), peradilan (siyasah qadha'iyah), hukum perang (siyasah harbiah) dan Administrasi negara (siyasah idariyah). ${ }^{9}$ T.M. Hasbi ashShiddieqi membagi ruang lingkup fiqh siyasah menjadi delapan bidang yaitu: (1) politik pembuatan perundang-undangan; (2) politik hukum; (3) politik peradilan; (4) politik moneter/ekonomi; (5) politik administrasi; (6) politik hubungan internasional; (7) politik pelaksanaan perundang-undangan; dan (8) politik peperangan. ${ }^{10}$

Kesimpulannya bahwa relasi antara fiqih siyasah terhadap pemenuhan hak pendidikan bagi penyandang disabilitas terletak pada politik pembuatan perundangundangan yang mana didalamnya mengelaborasi keberpihakan pemerintah dalam memberikan pemenuhan hak pendidikan bagi penyandang disabilitas melalui kebijakan hukum yang ditetapkan. Hal ini sangat krusial karena berkaitan dengan persamaan derajat dan keadilan bagi semua masyarakat tanpa mengenal keterbatasan antar sesama.

Kamus Bahasa Indonesia-Arab menjelaskan pengertian cacat mental atau tuna grahita atau penyandang disabilitas tingkatan kecerdasan yang sangat rendah, benarbenar bodoh, dungu. ${ }^{11}$ Sementara itu, Husna mengutip pandangan Imam al-Ghazali dalam Kitab Fathul Mun'in menjelaskan pengertian cacat ialah penyakit yang dapat menghilangkan akal manusia dan merusak kesehatan badan. ${ }^{12}$

Kajian fikih tidak membeda-bedakan tentang manusia normal maupun menusia

\footnotetext{
${ }^{8}$ Wahyu Abdul Jafar, "Fiqh Siyasah dalam Perspektif Al-Qur'an dan Al-Hadist,: Al-Imarah: Jurnal Pemerintahan dan Politik Islam, Vol. 3, No.1, 2018; 20.

${ }^{9}$ Muhammad Iqbal, Fiqh Siyasah (Jakarta: Gaya Media Pratama, 2007), 13.

${ }^{10}$ H. A. Djazuli, Fiqh Siyasah (Jakarta: Kencana, 2007), 30.

${ }^{11}$ Ghoffar Abdul, Kamus Bahasa Indonesia-Arab: Istilah Umum dan Kata-Kata Populer (Jakarta: PT RajaGrafindo Persada, 2000); 20.

${ }^{12}$ Ma'idatul Husna, "Hak Pendidikan Bagi Penyandang Disabilitas menurut Undang-Undang RI No. 8 Tahun 2016 tentang Penyandang Disabilitas dalam Perspektif Hukum Islam (Studi di Sekolah Luar Biasa (SLB) se Kabupaten Blitar)," Skripsi (Tulungagung: IAIN Tulungagung, 2018), 44.
} 
penyandang disabilitas. Karena maanusia merupakan sosok makhluk yang menjadi media, tempat bagi berbagai hak untuk kemaslahatan dirinya serta melakukan tanggung jawab yang harus di lakukan. Ketika mereka menetapkan bahwa manusia adalah media berbagai hak dan kewajiban, maka sifat-sifat yang demikian itulah yang merupakan ahliyyat al wujub (kelayakan mengemban tugas). ${ }^{13}$

Islam memandang kedudukan manusia di hadapan Allah adalah sama, meskipun dilahirkan dalam keadaan yang penuh keterbatasan secara fisik (disabilitas), hanya takwanyalah yang membedakan pandangan antara manusia satu dengan yang lainnya. Dalam konteks inilah mencari ilmu pengetahuan diwajibkan dalam rangka menuju derajat takwa. Islam memandang bahwa pendidikan merupakan suatu hak dan kewajiban bagi seluruh manusia, tanpa terkecuali, termasuk bagi penyandang disabilitas. Karena pada hakikatnya manusia adalah makhluk belajar, ia lahir tanpa memiliki pengetahuan, sikap dan kecakapan apa pun kemudian tumbuh dan berkembang menjadi mengetahui, mengenal dan menguasai banyak hal. Proses ini terjadi melalui suatu pembelajaran yang menggunakan potensi dan kapasitas diri yang mereka miliki. Penyandang disabilitas tunanetra, tunarungu, tunawicara, tunadaksa, dan tunagrahita, merupakan bagian dari umat manusia yang mempunyai hak dan kewajiban dasar yang sama untuk belajar dan menuntut ilmu seperti halnya manusiamanusia yang lain, dan tidak ada larangan bagi mereka untuk belajar bersama-sama dan beraktivitas bersama-sama dengan manusia yang lain. ${ }^{14}$

Secara fikih, penyandang disabilitas tetap dibebani kewajiban menjalankan kewajiban syariat (taklif) selama akal para penyandang disabilitas masih mampu bekerja dengan baik. Tentunya pelaksanaan kewajiban itu dengan mempertimbangkan kondisinya. Penyandang disabilitas diperbolehkan menjalankan kewajiban-kewajibanya sesuai dengan batas kemampuannya dengan tanpa mengurangi nilai afdlaliyyah sedikit pun.

\footnotetext{
${ }^{13}$ Huzaemah, Fiqih Anak: Metode Islam dalam Mengasuh dan Mendidik serta Hukum-Hukum yang Berkaitan dengan Aktifitas Anak (Jakarta: PT Al-Mawardi, 2004), 7.

${ }^{14}$ Akhmad Sholeh, "Islam dan Penyandang Disabilitas: Telaah Hak Aksesibilitas Penyandang Disabilitas dalam Sistem Pendidikan di Indonesia," Palastren, Vol. 8, No. 2, Desember 2015; 316-317.
} 
Lebih spesifik Alquran secara tegas menyampaikan pembelaan terhadap penyandang disabilitas, sebagai berikut:

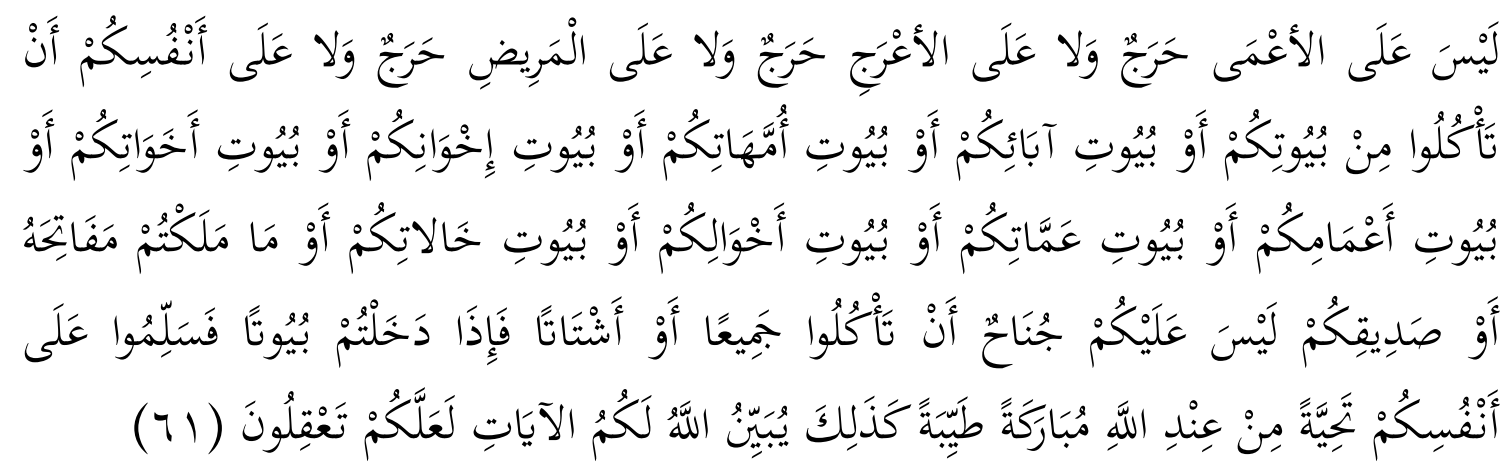

Terjemahnya:

Tidak ada halangan bagi orang buta, tidak (pula) bagi orang pincang, tidak (pula) bagi orang sakit, dan tidak (pula) bagi dirimu, makan (bersama-sama mereka) di rumah kamu atau di rumah bapak-bapakmu, di rumah ibu-ibumu, di rumah saudara-saudaramu yang laki-laki, di rumah saudara-saudaramu yang perempuan, di rumah saudara-saudara bapakmu yang laki-laki, di rumah saudara-saudara bapakmu yang perempuan, di rumah saudara-saudara ibumu yang laki-laki, di rumah saudara-saudara ibumu yang perempuan, (di rumah) yang kamu miliki kuncinya atau (di rumah) kawan-kawanmu. Tidak ada halangan bagi kamu makan bersama-sama mereka atau sendiri-sendiri. Apabila kamu memasuki rumah-rumah hendaklah kamu memberi salam (kepada penghuninya, yang berarti memberi salam) kepada dirimu sendiri, dengan salam yang penuh berkah dan baik dari sisi Allah. Demikianlah Allah menjelaskan ayat-ayat(-Nya) bagimu, agar kamu mengerti (QS an-Nūr/24: 61). ${ }^{15}$

QS an-Nūr/24 ayat 61 secara eksplisit menegaskan kesetaraan sosial antara penyandang disabilitas dan yang bukan penyandang disabilitas. Penyandang disabilitas harus diperlakukan secara sama dan diterima secara tulus, tanpa diskriminasi dan tanpa stigma negatif dalam kehidupan sosial. Perlindungan terhadap kaum difabel juga diperlihatkan oleh Alquran dalam ayat lainnya:

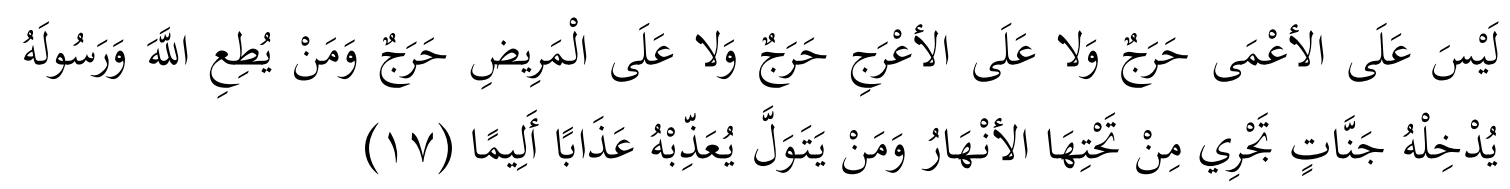

${ }^{15}$ Kementerian Agama RI., Ummul Mukminin: Al-Qur'an dan Terjemahan untuk Wanita (Jakarta Selatan: Penerbit Wali, 2010), 358. 
Terjemahnya:

Tidak ada dosa atas orang-orang yang buta, atas orang-orang yang pincang, dan atas orang-orang yang sakit (apabila tidak ikut berperang). Barangsiapa taat kepada Allah dan Rasul-Nya, Dia akan memasukkannya ke dalam surga yang mengalir di bawahnya sungai-sungai; tetapi barangsiapa yang berpaling, Dia akan mengazabnya dengan azab yang pedih (QS al-Fath/48:17). ${ }^{16}$

QS al-Fath/48 ayat 17 ini turun berkenaan dengan keresahan orang-orang yang memiliki keterbatasan fisik, baik karena cacat fisik maupun karena sakit dalam melaksanakan perintah berjihad, padahal ayat tersebut sesungguhnya diarahkan kepada orang munafik yang enggan berjuang, meskipun kondisi fisik mereka sangat memungkinkan. Oleh karena adanya ancaman Alquran terhadap kelompok yang tidak mau berjuang dan berjihad di jalan Allah swt. Sekelompok orang yang secara fisik memiliki keterbatasan merasa resah, lalu mengadu kepada Rasulullah saw., langkah terbaik apa yang seharusnya mereka ambil. Akibat keresahan ini maka turunlah QS alFath $/ 48$ ayat 17 tersebut. ${ }^{17}$

Penjelasan di atas dapat dipahami bahwa pada prinsipnya Alquran memberikan perlakuan khusus terhadap orang yang meskipun secara fisik terbatas, tetapi memiliki lahan beribadah serta kontribusi aktivitas sosial yang luas serta dapat memberikan kemanfaatan terhadap orang banyak. Dalil tersebut juga menjadi indikator penghargaan Islam terhadap kelompok yang memiliki keterbatasan fisik. Kemampuan seseorang tidak bisa diukur dengan kesempurnaan fisik, melainkan banyak faktor lain yang turut menentukan. Oleh karena itu, tidak ada pijakan teologis maupun normatif dalam Islam untuk mentolelir tindakan diskriminatif terhadap siapapun, termasuk para penyandang difabel.

Islam tidak membedakan siapa pun, karena di mata Allah swt. hanya ketakwaannya saja yang menjadi tolok ukur kemuliaan seseorang, lepas dari status sosial, kesempurnaan fisik, warna kulit, ras serta kebangsaan seseorang. Dalil-dalil dalam Alquran memberi legitimasi akan prinsip kesetaraan yang diajarkan Islam untuk menjauhkan diri dari sistem kelas atau strata sosial lainnya. Dengan demikian,

\footnotetext{
${ }^{16}$ Ibid., 513

${ }^{17}$ Khairunnas Jamal, Nasrulah Fatah dan Wilaela, "Eksistensi Kaum Difabel dalam Perspektif Al-Qur'an,” Jurnal Ushuluddin Vol. 25 No.2, Juli-Desember 2017; 232.
} 
kelompok difabel secara sosial diakui keberadaannya oleh Islam sebagai bagian dari umat secara umum, serta mereka memiliki hak dan kewajiban yang sama dengan muslim lainnya. $^{18}$

Oleh sebab itu, siapa pun wajib bertanggungjawab atas kelangsungan pemenuhan hak-hak penyandang disabilitas khususnya dibidang pendidikan yang merupakan bentuk perwujudan dari tujuan negara yaitu mencerdaskan kehidupan bangsa yang harus dirasakan oleh semua elemen masyarakat tanpa diskriminasi. Penting untuk disadari bahwa dalil Alquran memberikan dasar hukum yang harus dipedomani oleh semua pihak, khususnya pemerintah untuk bagaimana menindaklanjuti dengan peraturan pelaksana yang harus akomodatif terhadap kepentingan penyandang disabilitas yang berkaitan dengan hak-hak penyandang disabilitas dalam mendapatkan akses dan kemudahan pelayanan pendidikan yang baik dan merata di Negara Kesatuan Republik Indonesia.

\section{Pengaturan Hak Pendidikan Bagi Penyandang Disabilitas Perspektif Hukum Nasional}

Hak adalah sesuatu yang oleh sebab itu seseorang (pemegang) pemilik keabsahan untuk menuntut sesuatu yang dianggap tidak dipenuhi atau diingkari. Seseorang yang memegang hak atas sesuatu, maka orang tersebut dapat melakukan sesuatu tersebut sebagaimana dikehendaki, atau sebagaimana keabsahan yang dimilikinya. Kewajiban dasar manusia adalah seperangkat kewajiban yang apabila tidak dilaksanakan tidak memungkinkan terlaksananya dan tegaknya hak asasi manusia. ${ }^{19}$

Menurut L. J. Van Apeldoorn menegaskan hak adalah hukum yang dihubungkan dengan seorang manusia atau subyek hukum dan demikian menjelma menjadi suatu kekuasaan dan suatu hak timbul apabila hukum mulai bergerak. ${ }^{20}$

\footnotetext{
${ }^{18}$ Ibid.

${ }^{19}$ Lihat Republik Indonesia, Undang-Undang Nomor 39 Tahun 1999 tentang Hak Asasi Manusia, Pasal 1 angka 2. 1989), 120.

${ }^{20}$ C. S. T Kansil, Pengantar Ilmu Hukum dan Tata Hukum Indonesia (Jakarta: Balai Pustaka,
} 
Untuk mewujudkan kesamaan hak dan kesempatan bagi penyandang disabilitas menuju kehidupan yang sejahtera, mandiri, dan tanpa diskriminasi di perlukan peraturan perundang-undangan yang dapat menjamin pelaksanaannya. Dalam UndangUndang Nomor 8 Tahun 2016 tentang Penyandang Disabilitas dijelaskan beberapa hak penyandang diabilitas. Adapun hak tersebut terdapat pada pasal 5 sebagai berikut:

(1) Penyandang Disabilitas memiliki hak:
a. hidup;
b. bebas dari stigma;
c. privasi;
d. kedilan dan perlidungan hukum;
e. pendidikan;
f. pekerjaan, kewirausahaan, dan koperasi;
g. kesehatan;
h. politik;
i. keagamaan;
j. keolahragaan;
k. kebudayaan dan pariwisata;
1. kesejahteraan sosial;
m. aksesibilitas;
n. pelayanan publik;
o. perlindungan dari bencana;
p. habilitasi dan rehabilitasi;
q. konsesi;
r. pendataan;
s. hidup secara mandiri dan di libatkan dalam masyarakat;
t. berekspresi, berkomunikasi, dan memperoleh informasi;
u. berpindah tempat dan kewarganegaraan; dan
v. bebas dari tindakan dekriminasi, penelataran, penyiksaan, dan eksploitasi.

(2) Selain hak Penyandang Disabilitas sebagaimana dimaksud pada ayat (1), perempuan dengan disabilitas memiliki hak:

a. atas kesehatan reproduksi;

b. menerima atau menolak penggunaan alat kontrasepsi;

c. mendapatkan perlindungan lebih dari pengakuan diskriminasi berlapis; dan

d. untuk mendapatkan Perlindungan lebih dari tindak kekerasan dan eksploitasi seksual.

(3) Selain hak Penyandang Disabilitas sebagaimana di maksud pada ayat (1) anak Penyandang Disabilitas memiliki hak:
a. mendapatkan Perlidungan khusus dari deskriminasi, penelantaran, pelecehan, eksploitasi, serta kekerasan dan kejahatan seksual;
b. mendapatkan perawatan dan pengasuhan keluarga atau keluarga pengganti untuk tumbuh kembang secara optimal;
c. dilindungi kepentingannya dalam pengambilan keputusan;
d. perlakuan anak sejarah manusiawi sesuai dengan martabat dan hak anak; 
e. pemenuhan kebutuhan khusus;

f. perlakuan yang sama dengan ana lain untuk mencapai integrasi sosial dan perkembangan individu; dan

g. pendapatkan pendampingan sosial. ${ }^{21}$

Selain Undang-Undang Nomor 8 Tahun 2016 tentang Penyandang Disabilitas, juga terdapat perlindungan hukum yang mengatur tentang hak penyandang disabilitas, yaitu Undang-Undang Nomor 23 Tahun 2002 tentang Perlindungan Anak, sebagai berikut:

a. Pasal 9 ayat (2)

Selain hak anak sebagaimana dimaksud dalam ayat (1), khusus bagi anak menyandang cacat juga berhak memperoleh pendidikan luar biasa, sedangkan bagi anak yang memiliki keunggulan juga berhak mendapatkan pedidikan khusus. ${ }^{22}$

b. Pasal 12

Setiap anak yang menyandang cacat berhak memperoleh rehabilitasi, bantuan sosial, dan pemeliharaan taraf kesejahteraan sosial. ${ }^{23}$

Hukum Hak Asasi Manusia (HAM) Internasional menyatakan bahwa negara mempunyai kedudukan sebagai pemangku kewajiban (duty bearer) dalam pelaksanaan HAM. Dalam pelaksanaan HAM, kewajiban yang diemban negara terdiri atas tiga bentuk, yaitu:

1. Menghormati (to respect); kewajiban untuk menghormati (obligation to respect) adalah kewajiban negara untuk menahan diri untuk tidak melakukan intervensi, kecuali atas hukum yang sah (legitimate).

2. Melindungi (to protect); kewajiban negara untuk melindungi (the obligation to protect) adalah kewajiban untuk melindungi hak bukan hanya terhadap pelanggaran yang di lakukan negara, namun juga terhadap pelanggaran atau tindakan yang di lakukan pihak lain (non-negara) yang akan mengganggu perlindungan HAM.

\footnotetext{
${ }^{21}$ Republik Indonesia, Undang-Undang Nomor 8 Tahun 2016 tentang Penyandang Disabilitas, Pasal 5.

${ }^{22}$ Republik Indonesia, Undang-Undang Nomor 23 Tahun 2002 tentang Perlindungan Anak, Pasal 9 ayat (2).

${ }^{23}$ Ibid., Pasal 12.
} 
3. Memenuhi (to fulfill); kewajiban untuk memenuhi (the obligation to fulfill) adalah kewajiban negara untuk mengambil langkah-langkah legislatif, administratif, serta yudisial dan praktis untuk menjamin pelaksanaannya. ${ }^{24}$

Kewajiban atas tindakan meliputi upaya pemerintah dalam mewujudkan langkah-langkah pencapaian hak atas pedidikan. Sementara kewajiban atas hasil adalah capaian hasil yang di peroleh dari pelaksanaan hak atas pendidikan. Karena sifat perwujudannya yang bertahap, maka pelaksanaan kewajiban tidak semata-mata melihat dari hasil yang dicapai, tetapi juga langkah-langkah yang telah di ambil oleh pemerintah dalam rangka melaksanakan program-program pendidikan sebagai salah satu kewajibannya untuk menjamin pemenuhan hak atas pendidikan.

1. Pelaksanaan kewajiban atas tindakan (obligation of conduct), yaitu pelaksanaan kewajiban negara untuk mengambil langkah-langkah dalam pelaksanaan hak atas pendidikan yang dalam hal ini akan di lihat dari tiga hal, yaitu:

a. Langkah-langkah bidang legislasi yang dapat di lihat dari sisi produk legislasi (peraturan) yang dihasilkan.

b. Langkah-langkah bidang administrasi yang dapat di lihat dari programprogram atau kebijakan yang digulirkan.

c. Langkah-langkah bidang finansial yang dapat dilihat dari sisi penganggaran.

2. Pelaksanaan kewajiban atas hasil (obligation of result), yang akan dilihat dari capaian pelaksanaan kewajiban pemenuhan hak atas pendidikan. Lebih spesifik mengenai hak atas pendidikan. Komentar Umum Nomor 13 menyatakan bahwa hak atas pendidikan memuat fitur-fitur esensial yang satu sama lain saling berkaitan, yaitu:

a. Ketersediaan: ketersedian ini meliputi sarana dan prasarana pendidikan.

b. Aksesibilitas: berbagai institusi dan program pendidikan harus dapat di akses oleh semua orang, tanpa deskriminasi di dalam lingkup yuridiksi negara itu. Aksesibilitas mempunyai tiga dimensi berkarakteristik umum:

${ }^{24}$ Sofian Munawar Asgart, Yogyakarta: Kota Pendidikan Minus HAM (Yogyakarta: Penerbit Ombak, 2011), 9. 
1) Non-diskriminasi: pendidikan harus dapat di akses oleh semua orang, terutama oleh kelompok-kelompok yang paling rentan.

2) Aksesibilitas fisik: pendidikan harus secara fisik aman untuk di jangkau.

3) Aksesibilitas ekonomi: biaya pendidikan harus terjangkau oleh semua orang. Dimensi aksesibilitas ini menuntut Komentar Umum harus tunduk pada Pasal 13 ayat (2) yang menyebutkan bahwa pendidikan dasar harus "bebas biaya bagi semua orang".

c. Dapat diterima dan di adaptasi: bentuk dan substansi pendidikan, termasuk kurikulum dan metode-metode pengajaran, harus bisa di terima oleh siswasiswanya serta bersifat fleksibel sehingga dapat menyesuaikan diri dengan kebutuhan untuk mengubah masyarakat dan komunitas, serta mampu merespon kebutuhan para siswa dalam masyarakat dan tatanan budaya mereka yang beragam.

Azyumardi Azra berpendapat bahwa pendidikan lebih sekedar pengajaran. Pendidikan adalah suatu proses dimana suatu bangsa atau negara membina dan mengembangkan kesadaran diri diantara individu-individu. ${ }^{25}$ Lebih lanjut Nowak menyimpulkan bahwa terdapat empat tujuan dasar pendidikan yang telah disepakati secara universal, yaitu:

a. Memungkinkan umat manusisa secara bebas mengembangkan kepribadian dan martabatnya.

b. Memungkinkan umat manusia berpartisipasi secara aktif dalam masyarakat yang bebas dalam semangat saling bertoleransi dan penghormatan kepada orang tua.

c. Untuk mengembangkan penghormatan kepada orang tua, nilai kebangsaan dan lingkungan alam.

d. Mengembangkan penghormatan pada hak asasi manusia, kebebasan dasar dan pemeliharaan perdamaian. ${ }^{26}$

\footnotetext{
${ }^{25}$ Azyumardi Azra, Paradigma Membangun Karakter Bangsa Melalui Pendidikan (Jakarta:; Kompas, 2010), 12.

${ }^{26}$ Rhona K. M. Smith, Hukum Hak Asasi Manusia (Yogyakarta: PUSHAM UII, 2008), 123.
} 
Pendidikan telah menjadi hak bagi masyarakat dan pemerintah memiliki kewajiban untuk melakukan pemenuhan terhadap hak-hak masyarakat dalam mendapatkan pendidikan yang layak dan bermutu. Hal ini ditegaskan dalam UndangUndang Nomor 20 Tahun 2003 tentang Sistem Pendidikan Nasional, Pasal 5 bahwa:

1) Setiap warga negara mempunyai hak yang sama untuk memperoleh pendidikan yang bermutu;

2) Warga negara yang memiliki kelainan fisik, emosional, mental, intelektual, dan/atau sosial berhak memperoleh pendidikan khusus;

3) Warga negara di daerah terpencil atau terbelakang serta masyarakat terpencil berhak memperoleh pendidikan layanan khusus;

4) Warga negara yang memiliki potensi kecerdasan dan bakat istimewa berhak memperoleh pendidikan khusus;

5) Setiap warga negara berhak mendapat kesempatan meningkatkan pendidikan sepanjang hayat. ${ }^{27}$

Jika dicermati ketentuan Pasal 5 ayat (2) menegaskan bahwa pendidikan melingkupi semua elemen masyarakat termasuk warga negara yang memiliki kelainan fisik, emosional, mental, intelektual, dan/atau sosial. Pengaturan ini memberikan amanah kepada pemerintah untuk serius melaksanakan kebijakan/program kegiatan pendidikan yang berkepentingan langsung dengan para penyandang disabilitas yang pada prinsipnya adalah warga negara yang memiliki kesempatan yang sama untuk mendapatkan pendidikan yang layak dan bermutu.

Undang-undang tersebut telah memberikan perlindungan kepada penyandang disabilitas untuk mendapatkan pendidikan khusus sebagai wujud pemerintah dalam memberikan keadilan bagi penyandang disabilitas. Pendidikan khusus dan pendidikan layanan khusus ini diatur dalam hukum nasional Indonesia, yaitu:

1) Pendidikan khusus merupakan pendidikan bagi peserta didik yang memiliki tingkat kesulitan dalam mengikuti proses pembelajaran karena kelainan fisik, emosional, mental, sosial, dan/atau memiliki potensi kecerdasan dan bakat istimewa.

2) Pendidikan layanan khusus merupakan pendidikan bagi peserta didik di daerah terpencil atau terbelakang, masyarakat adat yang terpencil, dan/atau mengalami bencana alam, bencana sosial, dan tidak mampu dari segi ekonomi.

${ }^{27}$ Republik Indonesia, Undang-Undang Nomor 20 Tahun 2003 tentang Sistem Pendidikan Nasional, Pasal 5. 
3) Ketentuan mengenai pelaksanaan pendidikan khusus dan pendidikan layanan khusus sebagaimana dimaksud pada ayat (1) dan ayat (2) diatur lebih lanjut dengan peraturan pemerintah. ${ }^{28}$

Juga dijelaskan pula pada Undang-Undang Nomor 4 Tahun 1997 tentang Penyandang Cacat, yakni:

Setiap orang yang mempunyai kelainan fisik dan/atau mental, yang dapat menganggu atau merupakan rintangan dan hambatan baginya untuk melakukan secara selayaknya, yang terdiri dari, penyandang cacat fisik; penyandang cacat mental; penyandang cacat fisik dan mental. ${ }^{29}$

Menurut Undang-Undang Nomor 19 Tahun 2011 tentang Pengesahan Hak-Hak Penyandang Disabilitas, yaitu:

Penyandang disabilitas yaitu orang yang memiliki keterbatasan fisik, mental, intelektual atau sensorik dalam jangka waktu lama yang dalam berinteraksi dengan lingkungan dan sikap masyarakatnya dapat menemui hambatan yang menyulitkan untuk berpartisipasi penuh dan efektif berdasarkan kesamaan hak. $^{30}$

Menindaklanjuti undang-undang tersebut, maka Pemerintah dan Dewan Perwakilan Rakyat (DPR) membentuk suatu peraturan khusus berkaitan penyandang disabilitas yang resmi berlaku pada tahun 2016, yaitu Undang-Undang Republik Indonesia Nomor 8 Tahun 2016 tentang Penyandang Disabilitas. Dalam undangundang tersebut mengatur berkaitan dengan hak penyandang disabilitas yang mana salah satu hak dari penyandang disabilitas adalah pendidikan. ${ }^{31}$

Ketentuan hak pendidikan yang dimaksud meliputi:

a. mendapatkan pendidikan yang bermutu pada satuan pendidikan di semua jenis, jalur, dan jenjang pendidikan secara inklusif dan khusus;

b. mempunyai Kesamaan Kesempatan untuk menjadi pendidik atau tenaga kependidikan pada satuan pendidikan di semua jenis, jalur, dan jenjang pendidikan;

\footnotetext{
${ }^{28}$ Ibid. Pasal 32.

${ }^{29}$ Republik Indonesia, Undang-Undang Nomor 4 Tahun 1997 tentang Penyandang Cacat, Pasal 1 angka 1

${ }^{30}$ Republik Indonesia, Undang-Undang Nomor 19 Tahun 2011 tentang Pengesahan Hak-Hak Penyandang Disabilitas

${ }^{31}$ Republik Indonesia, Undang-Undang Nomor 8 Tahun 2016 tentang Penyandang Disabilitas, Pasal 5 ayat (1)
} 
c. mempunyai Kesamaan Kesempatan sebagai penyelenggara pendidikan yang bermutu pada satuan pendidikan di semua jenis, jalur, dan jenjang pendidikan; dan

d. mendapatkan Akomodasi yang Layak sebagai peserta didik. ${ }^{32}$

Ketentuan tersebut menegaskan bahwa penyandang disabilitas memiliki hak konstitusional yang wajib untuk dipenuhi oleh negara dalam rangka memberikan rasa keadilan kepada penyandang disabilitas. Hal ini dimaksudkan untuk memastikan semua penyandang disabilitas memiliki akses dalam mendapatkan pendidikan bermutu yang menjadi tugas pemerintah pusat dan pemerintah daerah. Pemberian tugas tersebut telah diatur dalam Pasal 40 Undang-Undang Republik Indonesia Nomor 8 Tahun 2016 tentang Penyandang Disabilitas yang berbunyi:

a. Pemerintah dan Pemerintah Daerah wajib menyelenggarakan dan/atau memfasilitasi pendidikan untuk Penyandang Disabilitas di setiap jalur, jenis, dan jenjang pendidikan sesuai dengan kewenangannya.

b. Penyelenggaraan dan/atau fasilitasi pendidikan untuk Penyandang Disabilitas sebagaimana dimaksud pada ayat (1) dilaksanakan dalam sistem pendidikan nasional melalui pendidikan inklusif dan pendidikan khusus.

c. Pemerintah dan Pemerintah Daerah wajib mengikutsertakan anak penyandang disabilitas dalam program wajib belajar 12 (dua belas) tahun.

d. Pemerintah Daerah wajib mengutamakan anak penyandang disabilitas bersekolah di lokasi yang dekat tempat tinggalnya.

e. Pemerintah Daerah memfasilitasi Penyandang Disabilitas yang tidak berpendidikan formal untuk mendapatkan ijazah pendidikan dasar dan menengah melalui program kesetaraan.

f. Pemerintah dan Pemerintah Daerah wajib menyediakan beasiswa untuk peserta didik Penyandang Disabilitas berprestasi yang orang tuanya tidak mampu membiayai pendidikannya.

g. Pemerintah dan Pemerintah Daerah wajib menyediakan biaya pendidikan untuk anak dari Penyandang Disabilitas yang tidak mampu membiayai pendidikannya. $^{33}$

Peraturan perundang-undangan tersebut sangat jelas telah memberikan jaminan kepada penyandang cacat untuk memperoleh haknya dalam dunia pendidikan tanpa adanya diskriminasi oleh siapa pun. Pelaksanaan tugas dan tanggung jawab ini utamanya bagi pemerintah, baik pemerintah pusat maupun pemerintah daerah.

\footnotetext{
${ }^{32}$ Ibid.

${ }^{33}$ Ibid., Pasal 40.
} 


\section{Pemenuhan Hak Pendidikan terhadap Penyandang Disabilitas}

Otonomi daerah Indonesia menganut asas desentralisasi dalam penyelenggaraan pemerintahan yang memberikan keleluasan untuk mengelola daerah agar dapat bergerak cepat dan maju dalam pelayanan publiknya. Kebijakan desentralisasi ini seyogyanya dimanfaatkan untuk pembangunan yang berbasis pada keadilan. Hal ini menjadi penting mengingat daerah harus mengedepankan kepentingan bersama dan memberikan kesempatan yang sama kepada semua masyarakat untuk mendapatkan hak-hak masyarakat yang telah diatur dalam peraturan perundang-undangan.

Otonomi seluas-luasmnya dapat dimaknai bahwa tugas, wewenang, hak dan kewajiban pemerintah daerah dilaksanakan dengan prinsip kemandirian dan independen serta segala kebijakan yang dilahirkan tidak bertentangan dengan kebijakan dengan pemerintah pusat. Hal ini merupakan konsekuensi logis dari prinsip negara kesatuan yang mana segala bentuk kebijakan pemerintah pusat dan daerah harus selaras dengan apa yang diamanatkan oleh peraturan perundang-undangan dalam rangka menghindari disorientasi kebijakan yang dapat berpotensi mengancam stabilitas negara. Daerah pun diberikan keleluasaan untuk menangani urusan pemerintahan yang diserahkan itu dalam rangka mewujudkan tujuan dibentuknya suatu daerah dan tujuan pemberian otonomi daerah itu sendiri terutama dalam memberikan pelayanan kepada masyarakat sesuai dengan potensi dan karakteristik pada masing-masing daerah tersebut.

Pemerintahan daerah dikaitkan dengan penyelenggaraan urusan pemerintahan oleh pemerintah daerah dan Dewan Perwakilan Rakyat Daerah (DPRD) menurut asas otonomi dan tugas pembantuan dengan prinsip otonomi seluas-luasnya dalam sistem dan prinsip Negara Kesatuan Republik Indonesia Tahun 1945. ${ }^{34}$ Menurut Mahfud MD bahwa otonomi merupakan pemberian kebebasan untuk mengurus rumah tangga sendiri, tanpa mengabaikan kedudukan pemerintah daerah sebagai aparat pemerintah pusat untuk menyelenggarakan urusan-urusan yang ditugaskan kepadanya. ${ }^{35}$

\footnotetext{
${ }^{34}$ Jimly Asshidiqie, Pokok-Pokok Hukum Tata Negara Indonesia Pasca Reformasi (Jakarta: PT. Bhuana Ilmu Populer, 2007), 411.

${ }^{35}$ Mahfud MD, Politik Hukum Indonesia (Jakarta: Pustaka LP3ES, 1998), 93.
} 
Mewujudkan otonomi bagi daerah agar memiliki keleluasaan dalam penyelenggaraan pemerintahan di daerah, maka menurut Agus Syamsuddin diperlukan beberapa hal sebagai berikut:

1. Self regulating power, yaitu kemampuan mengatur dan melaksanakan otonomi daerah demi kesejahteraan masyarakat di daerahnya.

2. Self modifying power, yaitu kemampuan melakukan penyesuaian-penyesuaian dari peraturan yang ditetapkan secara nasional dengan kondisi daerah.

3. Local political support, yaitu menyelenggarakan pemerintahan daerah yang mempunyai legitimasi luas dari masyarakat.

4. Financial recources, yaitu mengembangkan kemampuan dalam mengelola sumbersumber penghasilan dan keuangan yang memadai untuk membiayai kegiatankegiatan pemerintahan, pembangunan dan pelayanan masyarakat yang segera menjadi kebutuhannya.

5. Developing brain power, yaitu membangun sumberdaya manusia aparatur pemerintah dan masyarakat yang handal yang bertumpu pada kapabilitas intelektual dalam menyelesaikan berbagai masalah. ${ }^{36}$

UUD NRI Tahun 1945 merupakan landasan konstitusional bagi pemerintah daerah dalam menjalankan otonomi seluas-luasnya dengan memprioritaskan kebutuhan masyarakat yang semakin hari semakin cepat berkembang dengan kompleksitas permasalahannya. Kewenangan otonomi luas adalah keleluasan daerah untuk menyelenggarakan pemerintahan yang terbagi ke dalam beberapa klasifikasi urusan pemerintahan sebagaimana diatur dalam Undang-Undang Nomor 23 Tahun 2014 tentang Pemerintahan Daerah. Klasifikasi urusan pemerintahan sebagai berikut:

1) Urusan pemerintahan absolut adalah Urusan Pemerintahan yang sepenuhnya menjadi kewenangan Pemerintah Pusat.

2) Urusan pemerintahan konkuren adalah Urusan Pemerintahan yang dibagi antara Pemerintah Pusat dan Daerah provinsi dan Daerah kabupaten/kota. Urusan pemerintahan konkuren yang diserahkan ke Daerah menjadi dasar pelaksanaan Otonomi Daerah.

${ }^{36}$ Trilaksono Nugroho. "Reformasi dan Reorientasi Kebijakan Otonomi Daerah dalam Perspektif Hubungan Pemerintah Pusat-Daerah," Jurnal Administrasi Negara, I, 1, (2000): 13. 
3) Urusan pemerintahan umum adalah Urusan Pemerintahan yang menjadi kewenangan Presiden sebagai kepala pemerintahan. ${ }^{37}$

Urusan pemerintahan yang menjadi kewenangan daerah terdiri atas urusan pemerintahan wajib dan urusan pemerintahan pilihan. Lebih lanjut urusan pemerintahan wajib terdiri atas urusan pemerintahan yang berkaitan dengan pelayanan dasar dan urusan pemerintahan yang tidak berkaitan dengan Pelayanan Dasar. Urusan Pemerintahan Wajib yang berkaitan dengan Pelayanan Dasar adalah Urusan Pemerintahan Wajib yang sebagian substansinya merupakan Pelayanan Dasar. ${ }^{38}$

Urusan Pemerintahan Wajib yang berkaitan dengan Pelayanan Dasar meliputi:
a. pendidikan;
b. kesehatan;
c. pekerjaan umum dan penataan ruang;
d. perumahan rakyat dan kawasan permukiman;
e. ketenteraman, ketertiban umum, dan pelindungan masyarakat; dan
f. sosial. $^{39}$

Pendidikan merupakan hak konstitusional, yang dijamin implementasinya secara nasional berdasarkan konstitusi. Di Indonesia hak ini diakui dan dijamin di dalam Undang-Undang Dasar Negara Republik Indonesia Tahun 1945 (UUD NRI Tahun 1945). Tanggung jawab negara di dalam pendidikan dituangkan di dalam pasalpasal dalam UUD NRI Tahun 1945, dan sasaran pendidikan secara konkret adalah “...mencerdaskan kehidupan bangsa..." sebagaimana yang tertuang di dalam Pembukaan UUD NRI Tahun 1945. Tidak ada pembedaan atau bentuk diskriminasi terhadap penikmatan hak pendidikan termasuk penyandang disabilitas. Negara dalam hal ini juga mengupayakan untuk dapat memenuhi hak pendidikan dengan cara menyediakan akses dan sarana yang dapat membantu dan memberi kemudahan dalam pencapaian haknya dengan derajat kedisabilitasannya.

Penyandang disabilitas dilindungi hak pendidikannya dalam suatu undangundang yang bertujuan untuk meningkatkan pemberdayaan bagi penyandang disabilitas. Pemberdayaan adalah upaya untuk menguatkan keberadaan penyandang

\footnotetext{
${ }^{37}$ Republik Indonesia, Undang-Undang Nomor 23 Tahun 2014 tentang Pemerintahan Daerah, Pasal 9.

${ }^{38}$ Ibid., Pasal 11.

${ }^{39}$ Ibid., Pasal 12
} 
disabilitas dalam bentuk penumbuhan iklim dan pengembangan potensi, sehingga mampu tumbuh dan berkembang menjadi individu atau kelompok penyandang disabilitas yang tangguh dan mandiri

Hak atas pendidikan dijamin di dalam konstitusi UUD NRI Tahun 1945 sebagaimana yang tertuang di dalam Pasal:

a. Pasal $28 \mathrm{C}$

Setiap orang berhak mengembangkan diri melalui pemenuhan kebutuhan dasarnya, berhak mendapat pendidikan dan memperoleh manfaat dari ilmu pengetahuan dan teknologi, seni dan budaya, demi meningkatkan kualitas hidupnya dan demi kesejahteraan umat manusia. ${ }^{40}$

b. Pasal 28E ayat (1)

Setiap orang bebas memeluk agama dan beribadat menurut agamanya, memilih pendidikan dan pengajaran, memilih pekerjaan, memilih kewarganegaraan, memilih tempat tinggal diwilayah negara dan meninggalkannya, serta berhak kembali. $^{41}$

c. Pasal 31

1) Setiap warga negara berhak mendapat pendidikan.

2) Setiap warga negara wajib mengikuti pendidikan dasar dan pemerintah wajib membiayainya.

3) Pemerintah mengusahakan dan menyelenggarakan satu sistem pendidikan nasional, yang meningkatkan keimanan dan ketakwaan serta ahklak mulia dalam rangka mencerdaskan kehdupan bangsa yang diatur dengan UndangUndang.

4) Negara memprioritaskan anggaran pendidikan sekurang-kurangnya dua puluh persen dari anggaran pendapatan dan belanja negara serta dari aggaran pendapatan dan belanja daerah untuk memenuhi kebutuhan penyelenggaraan pendidikan nasional.

5) Pemerintah memajukan ilmu pengetahuan dan tekhnologi dengan menjunjung tinggi nilai-nilai agama dan persatuan bangsa untuk kemajuan peradaban serta kesejahteraan umat manusia. ${ }^{42}$

Undang-Undang Dasar Tahun 1945 dinyatakan bahwa setiap warga negara berhak atas pendidikan yang layak dan tanpa diskriminasi, tak terkecuali orang-orang yang berkebutuhan khusus atau penyandang disabilitas. sehingga negara memiliki

\footnotetext{
Perubahan II.

${ }^{40}$ Republik Indonesia, Undang-Undang Dasar Negara Republik Indonesia Tahun 1945,

${ }^{41}$ Ibid.

${ }^{42}$ Ibid., Perubahan IV.
} 
kewajiban untuk memenuhi, menghormati dan bahkan melindungi setiap hak pendidikan yang dimiliki oleh setiap warga negaranya, termasuk hak pendidikan bagi penyandang disabilitas. Pada dekade terakhir telah terjadi pergeseran paradigma pendidikan bagi penyandang disabilitas. Pendidikan dengan model segregasi dinilai tidak cukup memberikan kesempatan bagi penyandang disabilitas untuk hidup dan mengenyam pendidikan normal seperti peserta didik di sekolah sekolah reguler. Pemisahan penyandang disabilitas dari kenormalan tersebut telah menjadikan mereka seperti terasing. Penyandang disabilitas merasa bahwa mereka hidup di lingkungan yang ekslusif dari kenormalan dan merasa bahwa kenormalan yang terpisah dari mereka juga sebagai lingkungan yang ekslusif. Dari pemikiran tersebutlah lantas muncul paradigma pendidikan yang tidak lagi memisahkan penyandang disabilitas, namun sebaliknya menyatukan penyandang disabilitas dalam pendidikan reguler. Inilah yang kemudian dikenal dengan model pendidikan inklusif. ${ }^{43}$

Pelaksanaan pendidikan secara terencana dan teratur bertujuan agar pendidikan tersebut dapat mencapai tujuan pendidikan dimana dari waktu kewaktu terus berkembang sesuai dengan perkembangan zaman, terutama penyelenggaraan pendidikan terhadap penyandang disabilitas atau anak berkebutuhan khusus yang diselenggarakan secara inklusif. Pendidikan inklusif merupakan sebuah pelayanan pendidikan bagi peserta didik yang mempunyai kebutuhan pendidikan khusus di sekolah reguler yang tergolong luar biasa baik dalam arti kelainan, lamban belajar, berkesulitan belajar lainnya maupun kecerdasaran luar biasa. ${ }^{44}$

Jaminan perlindungan yang diatur dalam UUD NRI Tahun 1945 seyogyanya dapat ditindaklanjuti dalam kebijakan yang ditelurkan oleh pemerintah pusat dan pemerintah daerah sebagai wujud pertanggungjawaban terhadap amanah konstitusi. Namun pada prakteknya, peraturan pelaksana yang dapat mendukung perlindungan dan pemenuhan hak pendidikan bagi penyandang disabilitas belum sepenuhnya dilaksanakan dengan baik. Sebab, peraturan pelaksana dari Undang-Undang Nomor 8

\footnotetext{
${ }^{43}$ Dion Teguh Pratomol, Sudarsono, dan Mohammad Fadli, "Pelaksanaan Perlindungan Hak Atas Pendidikan Bagi Penyandang Disabilitas (People With Disability) di Universitas Negeri Gorontalo," Jurnal Hukum, 2015; 6.

${ }^{44}$ Mudhafar Anzari, et. al., "Hak Memperoleh Pendidikan Inklusif terhadap Penyandang Disabilitas," Syiah Kuala Law Journal, Vol. 2, No.1 April 2018; 58.
} 
Tahun 2016 tentang Penyandang Disabilitas perlu untuk ditindaklanjuti melalui pembentukan peraturan daerah sebagai dasar pengambilan kebijakannya.

\section{E. Kesimpulan}

Pengaturan pemenuhan hak pendidikan bagi penyandang disabilitas yang telah diatur dalam Undang-Undang Nomor 8 Tahun 2016 telah jelas memberikan perlindungan kepada penyandang disabilitas dalam mendapatkan pendidikan yang layak. Hal ini perlu ditindaklanjuti dalam bentuk peraturan pelaksana guna memastikan kebijakan pemenuhannya memiliki landasan hukum berupa peraturan daerah. Begitu pula halnya dalam hukum Islam sangat jelas diterangkan dalam beberapa suratnya, seperti QS al-Hujurat/49: 13 bahwa tidak ada perbedaan laki-laki dan perempuan, semuanya diciptakan untuk saling kenal-mengenal dan hanya takwalah yang membedakan di sisi Allah swt. Juga dijelaskan dalam QS Abasa/80: 1-11 bahwa tidak ada pembedaan antara yang fisiknya normal dan fisiknya tidak normal (penyandang disabilitas) dalam hal mendapatkan pengajaran.

Kewenangan pemerintah daerah yang tertuang dalam undang-undang nomor 23 tahun 2014 tentang pemerintahan daerah telah memberikan mandat kepada daerah untuk mengurus pendidikan sebagai urusan pemerintahan wajib yang berkaitan dengan pelayanan dasar sehingga pemerintah daerah dalam mengelola pendidikan mesti melaksanakan kewajibannya untuk melakukan pemenuhan hak pendidikan kepada masyarakat khusunya bagi penyandang disabilitas.

\section{Daftar Pustaka}

\section{Al-Qur’ān al-Karìm.}

Abdul, Ghoffar. Kamus Bahasa Indonesia-Arab: Istilah Umum dan Kata-Kata Populer. Jakarta: PT RajaGrafindo Persada, 2000.

Anzari, Mudhafar, et. al., "Hak Memperoleh Pendidikan Inklusif terhadap Penyandang Disabilitas," Syiah Kuala Law Journal, Vol. 2, No.1 April 2018.

Asgart, Sofian Munawar. Yogyakarta: Kota Pendidikan Minus HAM. Yogyakarta: Penerbit Ombak, 2011. 
Asshidiqie, Jimly. Pokok-Pokok Hukum Tata Negara Indonesia Pasca Reformasi. Jakarta: PT. Bhuana Ilmu Populer, 2007.

Azra, Azyumardi. Paradigma Membangun Karakter Bangsa Melalui Pendidikan. Jakarta:; Kompas, 2010.

Darwis, Rizal. "Hak Nafkah Batin Suami Istri dalam Perkawinan: Telaah Fikih dan Hukum Nasional Perspektif Jender," Disertasi. Makassar: UIN Alauddin Makassar, 2016.

Djazuli, H. A. Fiqh Siyasah. Jakarta: Kencana, 2007.

El Muhtaj, Majda. Dimensi-Dimensi HAM Mengurai Hak Ekonomi, Sosial dan Budaya. Jakarta: Raja Grafindo Persada, 2008.

Husna, Ma'idatul. 'Hak Pendidikan Bagi Penyandang Disabilitas menurut UndangUndang RI No. 8 Tahun 2016 tentang Penyandang Disabilitas dalam Perspektif Hukum Islam (Studi di Sekolah Luar Biasa (SLB) se Kabupaten Blitar)," Skripsi. Tulungagung: IAIN Tulungagung, 2018.

Huzaemah. Fiqih Anak: Metode Islam dalam Mengasuh dan Mendidik serta HukumHukum yang Berkaitan dengan Aktifitas Anak. Jakarta: PT Al-Mawardi, 2004.

Ibn Manzur. Lisān al-'Arabỉ. Juz 12. Bairūt: Dār al-Fikr, 1994.

International Labour Office. Kaidah ILO tentang Pengelolaan Penyandang Cacat di Tempat Kerja. Jakarta: ILO Publication, 2006.

Iqbal, Muhammad. Fiqh Siyasah. Jakarta: Gaya Media Pratama, 2007.

Jafar, Wahyu Abdul. "Fiqh Siyasah dalam Perspektif Al-Qur'an dan Al-Hadist, AlImarah: Jurnal Pemerintahan dan Politik Islam, Vol. 3, No.1, 2018.

Jamal, Khairunnas, Nasrulah Fatah dan Wilaela, "Eksistensi Kaum Difabel dalam Perspektif Al-Qur'an,” Jurnal Ushuluddin, Vol. 25 No.2, Juli-Desember 2017.

Kansil, C. S. T. Pengantar Ilmu Hukum dan Tata Hukum Indonesia.Jakarta: Balai Pustaka, 1989.

Kementerian Agama RI. Ummul Mukminin: Al-Qur'an dan Terjemahan untuk Wanita (Jakarta Selatan: Penerbit Wali, 2010.

Mahfud MD. Politik Hukum Indonesia. Jakarta: Pustaka LP3ES,1998.

Nugroho. Trilaksono. "Reformasi dan Reorientasi Kebijakan Otonomi Daerah dalam Perspektif Hubungan Pemerintah Pusat-Daerah," Jurnal Administrasi Negara, I, $1,2000$. 
Pratomol, Dion Teguh, Sudarsono, dan Mohammad Fadli, "Pelaksanaan Perlindungan Hak Atas Pendidikan Bagi Penyandang Disabilitas (People With Disability) di Universitas Negeri Gorontalo," Jurnal Hukum, 2015.

Republik Indonesia, Undang-Undang Dasar Negara Republik Indonesia Tahun 1945, Perubahan II, dan Perubahan IV.

Republik Indonesia, Undang-Undang Nomor 23 Tahun 2014 tentang Pemerintahan Daerah.

Republik Indonesia. Undang-Undang Nomor 19 Tahun 2011 tentang Pengesahan HakHak Penyandang Disabilitas.

Republik Indonesia. Undang-Undang Nomor 20 Tahun 2003 tentang Sistem Pendidikan Nasional.

Republik Indonesia. Undang-Undang Nomor 20 Tahun 2003 tentang Sistem Pendidikan Nasional.

Republik Indonesia. Undang-Undang Nomor 23 Tahun 2002 tentang Perlindungan Anak.

Republik Indonesia. Undang-Undang Nomor 23 Tahun 2014 tentang Pemerintahan Daerah.

Republik Indonesia. Undang-Undang Nomor 39 Tahun 1999 tentang Hak Asasi Manusia.

Republik Indonesia. Undang-Undang Nomor 4 Tahun 1997 tentang Penyandang Cacat.

Republik Indonesia. Undang-Undang Nomor 8 Tahun 2016 tentang Penyandang Disabilitas.

Sholeh, Akhmad. "Islam dan Penyandang Disabilitas: Telaah Hak Aksesibilitas Penyandang Disabilitas dalam Sistem Pendidikan di Indonesia.” Palastren, Vol. 8, No. 2, Desember 2015.

Smith, Rhona K. M. Hukum Hak Asasi Manusia. Yogyakarta: PUSHAM UII, 2008.

Al-Zuhaily, Wahbah. Ushul Fiqh: Kulliyat Da'wah al-Islami. Jakarta: Radar Jaya Pratama, 1997. 